\title{
ANALISIS PENGARUH INFLASI DAN TINGKAT SUKU BUNGA SBI TERHADAP RETURN OBLIGASI SYARIAH MUDHARABAH DAN IJARAH DI INDONESIA
}

\section{Indaf Tuliana}

Fakutlas Ekonomi Universitas Islam Negeri (UIN) Malang

Jl. Gajayana 50 Malang 65144 Tolp.0341-551354,558882

Faks.0341-572533,0341-558882

\section{Abstract}

In some recent years, Islamic financial and economy grows rapidly. This evidence can be proved by the growth of Syariah Financial Institution (LKS) in Indonesia that reached to $70 \%$. This phenomena was contradictory to Conventional Financial Institution that reached only one digit rate of average growth. One of the booming instruments in Islamic financial is syariah obligation. In general, this obligation which is offered by Emiten over subscribe. It become the altermative source of funds while the investors already sick and tired with the conventional financial portfolio products. Activities in capital market influenced by macro economy condition in a country. If the macro indicator stable, capital market activities would be stimulate. There are many indicators of macro economy used for calculate the national growth, such as the inflation and interest rate level. The purpose of this research is to knowing how the inflation and SBI interest rate level influences the syariah obligation return Mudharabah and Ijarah in Indonesia simultaneously. Population in this research is syariah obligation return Mudharabah and Ijarah level in Indonesia. The instrument used in this analysis is double linear regression. The results of this research are (1)Both inflation 
and SBI interest rate level significantly influences syariah obligation retum Mudharabah (2) Both inflation and SBI interest rate level were not significantly influences syariah obligation return ljarah.

Key word: syariah obligation retum, mudharabah, ijarah

\section{Pendahuluan}

Instrumen investasi dengan obligasi syariah telah mewamai pasar modal Indonesia sejak tahun 2002. Menurut Antonio, Syafii tersendatnya perkembangan obligasi syariah di Indonesia adalah karena jumlahnya yang terbatas dan berbanding terbalik dengan jumlah peminatnya yang banyak. Sehingga dibutuhkan political will dari pemerintah apakah dia sungguhsungguh dalam mengembangkan obligasi syariah atau tidak. (http:// unuru.tempointerakrif.com/hg/ekbis/2005/08/08/brk,200050808-64973, id.html yang di-update pada tanggal $24 \mathrm{Mei} 2006$ ). Dalam operasionalnya, obligasi syariah menawarkan beberapa alternatif skim bagi hasil yang tentu saja semuanya bebas bunga, serta memberikan tingkat keuntungan yang relatif besar. Sehingga tidak mengherankan apabila obligasi syariah lebih banyak diminati oleh investor yang bertujuan memperoleh manfaat secara ekonomi. Guna mewujudkan hal tersebut maka, pasar obligasi syariah harus diarahkan sedemikian rupa untuk dapat memenuhi keinginan investor yang bertujuan memperoleh manfaat secara ekonomi tersebut.

Berdasarkan uraian di atas maka peneliti tertarik untuk melakukan penelitian mengenai (1) Apakah inflasi dan tingkat suku bunga SBI berpengaruh secara simultan terhadap retum obligasi syariah Mudharabah di Indonesia, (2) Apakah inflasi dan tingkat suku bunga SBI berpengaruh secara simultan terhadap retum obligasi syariah ljarah di Indonesia.

\section{Inflasi}

Salah satu gejala ekonomi yang menarik untuk diperhatikan adalah inflasi. Hal ini dikarenakan kaitan yang menyinggung masalah inflasi dalam berbagai aspek, seperti ekonomi, sosial, politik. Menurut Nopirin (2000: 
25) inflasi adalah proses kenaikan harga-harga umum barang-barang secara terus menerus. Ini tidak berarti bahwa harga-harga berbagai macam barang itu naik dengan prosentase yang sama. Mungkin kenaikan tersebut tidaklah terjadi secara bersamaan. Yang penting terdapat kenaikan harga barang secara umum secara terus menenrus selama satu periode tertentu. Kenaikan yang hanya terjadi sekali (meskipun dengan prosentase besar) bukan merupakan inflasi.

Untuk mengukur kenaikan harga yang disebabkan oleh inflasi, dapat digunakan 3 (tiga) indikator (Nopirin, 2000: 25) yaitu: indeks biaya hidup (consumerprice index), index harga perdagangan besar (wholesale price index) dan GNP deflator. Inflasi tercermin dari naiknya indeks harga baikitu indeks harga konsumen (consumer price indeks), indeks harga produsen (producers price indeks), maupun indeks harga perdagangan besar (wholesaler price indeks), namun yang sering digunakan adalah indeks harga konsumen (IHK). Beberapa pengaruh inflasi terhadap perekonomian antara lain sebagai berikut (Samuelson, 2004: 387):

a) Pengaruh terhadap distribusi pendapatan dan kekayaan

b) Pengaruh terhadap efisiensi ekonomi

c) Pengaruh makro pada efisiensi dan pertumbuhan

\section{Sertifikat Bank Indonesia}

Sertifikat Bank Indonesia adalah surat berharga atas unjuk dalam rupiah yang diterbitkan oleh Bank Indonesia sebagai pengakuan hutang berjangka waktu pendek dengan sistem diskonto (www.bi.go.id)

Melalui penggunaan SBI tersebut Bank Indonesia dapat secara tidak langsung mempengaruhi tingkat bunga dipasar uang dengan cara mengumumkan stop of rate (SOR). SOR adalah tingkat suku bunga yang diterima oleh Bank Indonesia atas penawaran tingkat bunga dari peserta lelang. Selanjutnya, SOR tersebut akan dapat dipakai sebagai indikator bagi tingkat suku bunga transaksi di pasar uang pada umumnya. (Siamat, 2000: 220). 


\section{Hubungan SBI terhadap Perekonomian Indonesia}

SBI membawa dampak yang luas dalam perekonomian Indonesia. Dampak kenaikan SBI ini bisa secar positif maupun negatif. Secara positif dampak yang akan ditimbulkan adalah memperkuat nilai tukar, menekan inflasi, memikat investor asing untuk menukarkan dollar ke rupiah dan memancing dana masyarakat ke bank. Sedangkan dampak negatifnya adalah bahwa naiknya SBI akan berdampak pada tingkat suku bunga tabungan (deposito) yang pada gilirannya mengakibatkan naiknya tingkat suku bunga pinjaman. Naiknya tingkat suku bunga pinjaman ini akan membuat terburuknya sektor riil Sektor riil akan tidak mampu untuk menanggung beban bunga kredit yang semakin tinggi. Akibatnya akan banyak kredit macet.

Menurut Sabirin (info bank: 1998), kenaikan suku bunga berdampak pada dua hal, yaitu : (1) Perbedaan yang cukup tinggi dari Interest Rate Different telah meningkatkan aliran masuk modal, (2) Mendorong kelebihan likuiditas di masyarakat kembali ke bank, sehinggga berdampak kurangnya tekanan terhadap inflasi dari sisi Exsess Supply of Money.

\section{Obligasi Syariah}

Menurut Fatwa Dewan Syariah Nasional (DSN) Majelis Ulama Indonesia (MUI) No. 32/DSN-MUI/IX/2002 (2003: 200), obligasi syariah adalah surat berharga jangka panjang berdasarkan prinsip syariah yang dikeluarkan Emiten kepada pemegang obligasi syariah yang mewajibkan Emiten untuk membayar pendapatan kepada pemegang obligasi syariah berupa bagi hasil/mangin/fee serta membayar kembali dana obligasi pada saat jatuh tempo. Untuk membedakan antara obligasi konvensional dengan obligasi syariah, tentunya ada hal-hal tertentu yang harus dipenuhi oleh Investor sebagai pemilik modal dan Emiten sebagai penerbit obligasi syariah. Fatwa Dewan Syariah Nasional NO: 32/DSN-MUT/IX/2002, ada beberapa point yang harus diperhatikan dalam operasional obligasi syariah, diantaranya: 
a) Jenis usaha issuer adalah jenis usaha halal yang tidak bertentangan dengan syariah. Serta tetap memperhatikan substansi Fatwa Dewan Syariah Nasional Majelis Ulama Indonesia No. 20/DSN-MUI/IV/2001 tentang pedoman pelaksanaan investasi untuk reksadana syariah. Hal ini sangat sesuai dengan ajaran Islam, yang menyuruh umatnya untuk berusaha dan bekerja dalam ruang lingkup halal sekaligus baik, serta menjauhi langkah-langkah syaitan.

b) Pendapatan (hasil) investasi yang dibagikan harus bersih dari unsur nonhalal. Sesuai dengan keterangan pada Modal/12/Oktober 2003: 70, bahwa pendapatan atau (hasil) investasi yang dibagikan Emiten (mudharib) kepada pemegang obligasi syariah mudhatabah (shahibul maal) harus bersih dari unsur non halal

c) Pendapatan (hasil) yang diperoleh pemegang obligasi syariah sesuai dengan akad yang digunakan.

d) Pemindahan kepemilikan obligasi syariah mengikuti akad-akad yang digunakan.

Saat ini di Indonesia mengenal adanya dua jenis obligasi, yaitu obligasi mudharabah dan obligasi ijarah.

\section{a. Mudharabah (Muqaradhah)/Qiradh}

Sesuai dengan Fatwa Dewan Syariah Nasional No. 33/DSN-MUI/IX/ 2002, bahwa obligasi syariah mudharabah adalah obligasi syariah yang berdasarkan aqad mudharabah dengan memperhatikan substansi Fatwa Dewan Syariah Nasional MUI No. 7/DSN-MUI/IV/2000, tentang pembiayaan mudharabah. Mudharabah merupakan investasi bagi hasil (profit-loss shairing). Akad mudharabah adalah akad kerjasama antara dua pihak, dimana pihak pertama (shahibul maal/investor) menyediakan modal, sedangkan pihak kedua (Mudharib/Emiten) bertindak selaku pengelola, dan keuntungan dibagi diantará mereka sesuai dengan kesepakatan dimuka yang dituangkan dalam kontrak (Gun, 2004: 10). 
b. Ijarah

Dalam obligasi syariah ijarah, keuntungannya sudah dapat diketahui secara pasti sejak awal, karena sifatnya sebagai sewa atas guna barang (fee/sewa). Maka hasil investasi bersifat mendekati pasti karena merupakan imbalan sewa/upah atas pemakaian manfaat dari obyek pembiayaan. Dalam transaksi ijarah ini, ada obyek yang dipindahtangankan secara manfaat dan bukan secara kepemilikan. Kewajiban pengelola adalah menjalankan obyek ijarah tersebut dan membagikan fee ijarah (pendapatan hasil sewa) kepada pemilik obyek ijarah berdasarkan waktu yang telah ditentukan sebesar kesepakatan diawal.

\section{c. Tingkat Retum Obligasi Syariah Mudharabah}

M. Gunawan Yasni menyatakan bahwa dalam obligasi syariah dengan akad mudharabah, seorang pengusaha proyek adalah pemegang amanah terhadap modal yang diterima dari pemilik modal (venture capital company) dimana modal merupakan titipan/amanah dalam konsep wadiah yang dapat dimanfaatkan untuk memperoleh keuntungan. Pengusaha saat menjalankan proyek yang berkaitan dengan akad mudharabah adalah bertindak sebagai wakil pemilik modal, dan jika pengusaha memperoleh keuntungan maka pengusaha bertindak sebagai rekan pemilik modal, sehingga keuntungan tersebut harus dibagikan sesuai dengan prinsip musyarakah yang mengharuskan adanya bagi hasil yang adil antara rekan perkongsian.

\section{d. Tingkat Return Obligasi Syariah ljarah}

Skim ijarah (sewa) dinilai cukup prospektif bagi para Emiten yang bemiat menerbitkan obligasi syariah. Skim ini dalam beberapa hal lebih menguntungkan dari pada skim mudharabah (bagi hasil) (Republika Online, 2006). Obligasi ijarah ini menggunakan aqad sewa, sehingga besar retum yang diberikan sama sepanjang waktu obligasi berlaku (Retum 
Obligasi Syariah Lebih Tinggi, 06 Juni 2006, http://www.syariahmandiri.co.id/berita/details.php?cid=1\&id=64).

\section{Metode Penelitian}

a. Populasi dan Sampel

Populasi dalam penelitian ini adalah tingkat retum obligasi ijarah dan mudharabah di Indonesia. Sedangkan tehnik sampling yang digunakan dalam penelitian ini adalah purposive sampling. Sampel yang digunakan dalam penelitian ini adalah tingkat retum obligasi ljarah dan Mudharabuh di Indonesia bulan November tahun 2004 sampai dengan bulan April tahun 2006.

\section{b. Pengumpulan Data}

Sumber data yang digunakan dalam penelitian ini adalah data sekunder yang diperoleh dari Bank Indonesia yang berupa berupa : tingkat inflasi, ingkat suku bunga SBI dan retum obligasi ljarah dan Mudrarabah. Data ringkat inflasi dan tingkat suku bunga SBI diperoleh dari Statistik Ekonomi Keuangan Indonesia dari periode November 2004-April 2006. Sedangkan tingkat return obligasi syariah ijarah dan mudharabah didapatkan dari informasi penawaran obligasi melalui Over The Counter-Fixed Income yang disediakan oleh Bursa Efek Surabaya/Surabaya Stock Exchange (BAPEPAM: 2003), periode November 2004-April 2006 Berikut ini adalah data Emiten dan obligasi syariah yang diterbitkan, yang listing di Bursa Efek Surabaya (BES). 


\section{Tabel 1}

Daftar Nama Emiten dan Obligasi Syariah yang diterbitkan

\begin{tabular}{|c|c|c|}
\hline No & Nama Emiten & Obligasi Syariah yang Diterbitkan \\
\hline 1 & PT. Apexindo Pratama Duta Tbk & $\begin{array}{l}\text { Obligasi Syariah Ijarah Apexindo Pratama } \\
\text { Duta I Tahun } 2005\end{array}$ \\
\hline 2 & PT. Berlina Tbk & $\begin{array}{l}\text { Obligasi Syariah ljarah Berlina I Tahun } \\
2004\end{array}$ \\
\hline 3 & PT. Citra Sari Makmur & $\begin{array}{l}\text { Obligasi Syariah ljarah Citra Sari Makmur } \\
\text { I Tahun } 2004\end{array}$ \\
\hline 4 & $\begin{array}{l}\text { PT. Humpuss Intermoda } \\
\text { Transportasi Tbk }\end{array}$ & Obligasi Syariah Ijarah I HITS Tahun 2004 \\
\hline \multirow{2}{*}{5} & \multirow{2}{*}{ PT. Indosat Tbk } & $\begin{array}{l}\text { Obligasi Syariah ljarah Indosat Tahun } \\
2005\end{array}$ \\
\hline & & $\begin{array}{l}\text { Obligasi Syariah Mudharabah Indosat } \\
\text { Tahun } 2002\end{array}$ \\
\hline 6 & PT. Matahari Putra Prima Tbk & $\begin{array}{l}\text { Obligasi Syariah Ijarah I Matahari Putra } \\
\text { Prima Tahun } 2004\end{array}$ \\
\hline 7 & $\begin{array}{l}\text { PT. Perkebunan Nusantara VII } \\
\text { (Persero) }\end{array}$ & $\begin{array}{l}\text { Obligasi Syariah Mudharabah PTPN VII } \\
\text { Tahun } 2004\end{array}$ \\
\hline 8 & PT. CSM Corpotama & $\begin{array}{l}\text { Obligasi Syariah Ijarah Indorent I Tahun } \\
2004\end{array}$ \\
\hline 9 & PT. Ricky Putra Globalindo Tbk & $\begin{array}{l}\text { Obligasi Syariah ljarah Ricky Putra } \\
\text { Globalindo Tahun } 2005\end{array}$ \\
\hline 10 & $\begin{array}{l}\text { PT. Sona Topas Tourism Industry } \\
\text { Tbk }\end{array}$ & $\begin{array}{l}\text { Obligasi Syariah ljarah Sona Topas } \\
\text { Tourism Industry Tahun } 2004\end{array}$ \\
\hline 11 & PT. Bank Bukopin & $\begin{array}{l}\text { Obligasi Syariah Mudharabah Bank } \\
\text { Bukopin Tahun } 2003\end{array}$ \\
\hline 12 & $\begin{array}{l}\text { PT. Bank Pembangunan daerah } \\
\text { Sumatera Selatan }\end{array}$ & $\begin{array}{l}\text { Obligasi Syariah I Subordinasi Bank } \\
\text { Muamalat Tahun } 2003\end{array}$ \\
\hline 13 & PT. Bank Syariah Mandiri & $\begin{array}{l}\text { Obligasi Syariah Mudharabah Bank } \\
\text { Syariah Mandiri Tahun } 2003\end{array}$ \\
\hline 14 & PT. Berlian laju Tanker Tbk & $\begin{array}{l}\text { Obligasi Syariah Mudharabah Berlian Laju } \\
\text { Tanker Tahun } 2003\end{array}$ \\
\hline 15 & PT. Ciliandra Perkasa & $\begin{array}{l}\text { Obligasi Syariah Mudharabah Ciliandra } \\
\text { Perkasa Tahun } 2003\end{array}$ \\
\hline
\end{tabular}

Ulul Albab, Vol. 9 No. 1, 2008 


\section{Analisis Data}

Teknik analisa data yang digunakan untuk memecahkan masalah adalah:

1. Uji Asumsi Klasik
a) Uji Normalitas
b) Uji Kolinieritas Ganda (Uji Multikolinieritas)
c) Uji Autokorelasi

2. Regresi Linier Berganda

$$
\begin{aligned}
& Y=a o+a_{1} X_{1}+a_{2} X_{2}+a_{3} X_{3}+\ldots+a_{k} X_{k} \\
& Y=\text { Return obligasi syariah } \\
& \text { ao }=\text { konstanta } \\
& \text { a } 1,2=\text { koefisien regresi } \\
& \mathrm{X} 1=\text { inflasi } \\
& \mathrm{X} 2=\text { tingkat suku bunga SBI }
\end{aligned}
$$

\section{Uji F}

Untuk mengetahui apakah variabel bebas mempunyai pengaruh nyata atau tidak terhadap variabael terikat maka digunakan rumus : (Silalahi, 2002: 86)

$$
\begin{gathered}
R^{2} /(k-1) \\
\left(1-R^{2}\right) /(n-k) \\
\mathrm{R}=\text { koefisien regresi } \\
\mathrm{k}=\text { banyaknya variabel bebas } \\
\mathrm{n}=\text { banyaknya anggota sampel }
\end{gathered}
$$




\section{- HASIL ANALISIS DATA}

\section{a. Analisis Regresi pada Return Obligasi Syariah ljarah}

\section{Uji Normalitas}

a) Data Return Obligasi Syariah Ijarah

Diperoleh hasil perhitungan kolmogorov-smimov sebesar 1,228 dengan tingkat signifikansi 0,098 sehingga nilai signifikansinya di atas $1 \%$. Dengan memperhatikan hasil tersebut dapat dinyatakan bahwa data variabel retum obligasi syariah ljarah mendekati distribusi normal.

b) Data Tingkat Suku Bunga SBI

Diperoleh hasil perhitungan kolmogorov-smimov sebesar 1,666 dengan tingkat signifikansi 0,008 sehingga nilai signifikansinya dibawah $1 \%$. Dengan memperhatikan hasil tersebut dapat dinyatakan bahwa data variabel tingkat suku bunga SBI tidak berdistribusi normal. Sehingga data perlu dilakukan transformasi dengan menggunakan log. Hasil transformasi diperoleh perhitungan kolmogorov-smirnov sebesar 1,620 dengan tingkat signifikansi 0,010 sehingga nilai signifikansinya sebesar $1 \%$. Dengan memperhatikan hasil tersebut dapat dinyatakan bahwa data variabel return obligasi syariah Ijarah mendekati distribusi normal.

c) Data Inflasi

Diperoleh hasil perhitungan kolmogorov-smirnov sebesar 1,017 dengan tingkat signifikansi 0,252 sehingga nilai signifikansinya di atas $5 \%$. Dengan memperhatikan hasil tersebut dapat dinyatakan bahwa data variabel inflasi mengikuti distribusi normal.

\section{Persamaan Regresi}

Persamaan regresi linier berganda adalah untuk mengetahui pengaruh variabel bebas terhadap variabel terikat sebagai berikut:

$$
Y=b_{0}+b_{1} X_{1}+b_{2} X_{2}
$$

Dimana: 


$$
\begin{aligned}
& Y=\text { Retum Obeligasi Syariah ljarah } \\
& X_{1}=\text { Suku Bunga SBI } \\
& X_{2}=\text { Inflasi }
\end{aligned}
$$

Hasil uji regresi berganda ditunjukkan tabel di bawah ini:

\begin{tabular}{|c|c|c|c|c|}
\hline Variabel & B & $\mathbf{t}$ & Sig $t$ & Ket. \\
\hline Konstanta & $3.4 E+07$ & & & \\
\hline $\begin{array}{l}\text { Suku bunga } \\
\text { Indonesia }\left(X_{1}\right)\end{array}$ & $3.4 \mathrm{E}+09$ & 1.020 & 0.313 & $\begin{array}{c}\text { Tidak } \\
\text { Signifikan }\end{array}$ \\
\hline Inflasi $\left(X_{2}\right)$ & $-1.8 E+08$ & -0.327 & 0.745 & $\begin{array}{c}\text { Tidak } \\
\text { Signifikan }\end{array}$ \\
\hline $\mathbf{R}$ & 0,029 & & & \\
\hline R Square & 0,029 & & & \\
\hline Fhitung & 0.772 & & & \\
\hline Sig F & 0.467 & & & \\
\hline
\end{tabular}

\section{Tabel 2}

Hasil Uji Regresi Linier Berganda

Sumber : Hasil Analisis

Berdasarkan tabel tersebut, ditentukan persamaan bentuk variabelvariabel bebas $(X)$ tingkat suku bunga SBI dan inflasi terhadap retum obligasi syariah Ijarah $(Y)$ sebagai berikut:

$$
\mathrm{Y}=3.4 \mathrm{E}+07+3.4 \mathrm{E}+09 \mathrm{X}_{1}-1.8 \mathrm{E}+08 \mathrm{X}_{2}
$$

Dari persamaan regresi linier berganda diatas dapat dianalisis hal-hal sebagai berikut:

bo $=3.4 \mathrm{E}+07$ artinya, apabila nilai variabel-variabel tingkat suku bunga SBI inflasi sama dengan 0 , maka return obligasi syariah ljarah akan naik sebesar 3.4E+07. 
$\mathrm{b}_{1}=3.4 \mathrm{E}+09$ artinya, apabila nilai variabel tingkat suku bunga SBI naik satu satuan, maka variabel return obligasi syariah ljarah akan naik sebesar $3.4 \mathrm{E}+09$ satuan, dengan asumsi variabel bebas yang lain konstan. Hal ini dapat diartikan tingkat suku bunga SBI yang ada telah memberikan nilai positif dan meningkatkan return obligasi syariah Ijarah.

$\mathrm{b}_{2}=-1.8 \mathrm{E}+08$ artinya, apabila nilai variabel inflasi turun satu satuan, maka retum obligasi syariah ljarah akan naik sebesar $1.8 \mathrm{E}+08$ dengan asumsi variabel bebas yang lain konstan. Hal ini dapat diartikan inflasi yang ada telah memberikan nilai negatif dan menaikkan return obligasi syariah ljarah.

\section{Uji F}

Dari nilai $F_{\text {hitung }}$ menunjukkan nilai sebesar 0.772 (signifikansi $F=$ $0,467)$. Jadi Sig $F>5 \%(0,467>0,05)$ berarti secara bersama-sama variabel tingkat suku bunga $\mathrm{SBI}\left(\mathrm{X}_{1}\right)$ dan inflasi $\left(\mathrm{X}_{2}\right)$ tidak berpengaruh signifikan terhadap variabel return obligasi ljarah $(Y)$. Dengan demikian hipotesis yang menduga bahwa ada pengaruh yang signifikan dari variabel tingkat suku bunga SBI dan inflasi secara bersama-sama terhadap variabel retum obligasi syariah ljarah tidak terbukti kebenarannya. Dari nilai $R$ Square menunjukkan nilai sebesar 0,029 atau 2,9\%. Artinya bahwa variabel return obligasi syariah Ijarah (Y) dipengaruhi sebesar $2,9 \%$ oleh tingkat suku bunga SBI (X1) dan inflasi (X2) sedangkan sisanya 97,1\% dipengaruhi oleh variabel lain di luar 2 variabel bebas yang diteliti.

Dari hasil di atas menunjukkan bahwa secara simultan baik variabel tingkat suku bunga SBI maupun inflasi tidak berpengaruh signifikan terhadap retum obligasi syariah ljarah.

\section{b. Analisis Regresi pada Return Obligasi Syariah Mudharabah}

\section{Uji Normalitas}

a) Data Retum Obligasi Syariah Mudharabah

Berdasarkan analisis data diperoleh hasil kolmogorov-smimov pada lampiran 2 sebesar 1,011 dengan tingkat signifikansi 0,258 sehingga 
nilai signifkansinya di atas 5\%. Dengat memperhatikon hasil tersebut dapat dinyatakan bahwa data variabel return obligasi syariah Mudharabah mendekatidistribusi normal.

b) Data Tingkat Suku Bunga SBI

Diperoleh hasil perhitungan kolmogorov-smirnov sebesar 1,413 dengan tingkat signifikansi 0,037 sehingga nilai signifikansinya di atas $1 \%$. Dengan memperhatikan hasil tersebut dapat dinyatakan bahwa data variabel tingkat suku bunga SBI distribusi normal.

c) Data Inflasi

Diperoleh hasil perhitungan kolmogorov-smirnov sebesar 0,600 dengan tingkat signifikansi 0,864 sehingga nilai signifikansinya di atas 5\%. Dengan memperhatikan hasil tersebut dapat dinyatakan bahwa data variabel inflasi mengikuti distribusi normal.

\section{Persamaan Regresi}

Persamaan regresi linier berganda adalah untuk mengetahui pengaruh variabel bebas terhadap variabel terikat sebagai berikut:

$$
Y=b_{0}+b_{1} X_{1}+b_{2} X_{2}
$$

Dimana:

$$
\begin{aligned}
& \mathrm{Y}=\text { Return Obeligasi Syariah Mudharabah } \\
& \mathrm{X}_{1}=\text { Tingkat Suku Bunga SBI } \\
& \mathrm{X}_{2}=\text { Inflasi }
\end{aligned}
$$

Hasil uji regresi berganda ditunjukkan pada tabel di bawah ini: 
Tabel 3

Hasil Uji Regresi Linier Berganda

\begin{tabular}{|c|c|c|c|c|}
\hline Variabel & $\mathbf{B}$ & $t$ & Sig t & Ket. \\
\hline Konstanta & $8.8 E+09$ & & & \\
\hline $\begin{array}{l}\text { Suku bunga } \\
\text { Indonesia }\left(X_{1}\right)\end{array}$ & $-6.6 E+08$ & -6.008 & 0.000 & Signifikan \\
\hline Inflasi $\left(X_{2}\right)$ & $1.3 E+08$ & 3.012 & 0.005 & Signifikan \\
\hline $\mathrm{R}$ & 0.745 & & & \\
\hline R Square & 0.555 & & & \\
\hline Fhimung & 24.284 & & & \\
\hline Sig F & 0.000 & & & \\
\hline
\end{tabular}

Sumber : Hasil Analisis

Berdasar tabel tersebut, ditentukan persamaan bentuk variabelvariabel bebas $(X)$ tingkat suku bunga SBI dan inflasi terhadap retum obligasi syariah Mudharabah (Y) sebagai berikut:

$$
Y=8.8 \mathrm{E}+09-6.68 \mathrm{E}+08 \mathrm{X}_{1}+1.3 \mathrm{E}+08 \mathrm{X}_{2}
$$

Dari persamaan regresi linier berganda diatas dapat dianalisis halhal sebagai berikut:

bo $=8.8 \mathrm{E}+09$ artinya, apabila nilai variabel-variabel tingkat suku bunga SBI dan inflasi sama dengan 0 , maka retum obligasi syariah Mudharabah akan naik sebesar 8.8E+09.

$\mathrm{bl}=-8.8 \mathrm{E}+08$ artinya, apabila nilai variabel tingkat suku bunga SBI turun satu satuan, maka variabel return obligasi syariah Mudharabah akan naik sebesar $8.8 \mathrm{E}+08$ satuan, dengan asumsi variabel bebas yang lain konstan. Hal ini dapat diartikan tingkat suku bunga SBI yang ada telah memberikan nilai negatif dan meningkatkan retum obligasi syariah Mudharabah.

$\mathrm{b} 2=1.3 \mathrm{E}+08$ artinya, apabila nilai variabel inflasi naik satu satuan, maka return obligasi syariah Mudharabah akan naik sebesar 
1.3E +08 dengan asumsi variabel betas yang lair konstan. Hal ini dapat diartikan inflasi yang ada telah memberikan nilai positif dan menaikkan return obligasi syariah Mudharabah.

\section{Uji F}

Dari nilai $\mathrm{F}_{\text {hituns }}$ menunjukkan nilai sebesar 24.284 (signifikansi $\mathrm{F}=$ $0,000)$. Jadi Sig $F<5 \%(0,0.000<0,05)$ berarti secara bersama-sama variabel tingkat suku bunga $\mathrm{SBI}\left(\mathrm{X}_{1}\right)$ dan inflasi $\left(\mathrm{X}_{2}\right)$ berpengaruh signifikan terhadap variabel retum obligasi syariah Mudharabah ( $Y$ ). Dengan demikian hipotesis yang menduga bahwa ada pengaruh yang signifikan dari variabel tingkat suku bunga $\mathrm{SBI}$ dan inflasi secara bersamasama terhadap variabel retum obligasi syariah Mudharabah terbukti kebenarannya.Dari nilai $\mathrm{R}$ Square menunjukkan nilai sebesar 0,555 atau 55,5\%. Artinya bahwa variabel recum obligasi syariah Mudharabah (Y) dipengaruhi sebesar $55,5 \%$ oleh tingkat suku bunga SBI (X1) dan inflasi (X2) sedangkan sisanya $44.5 \%$ dipengaruhi oleh variabel lain di luar 2 variabel bebas yang diteliti. Dari hasil di atas menunjukkan bahwa secara simultan baik variabel tingkat suku bunga SBI maupun inflasi berpengaruh signifikan terhadap retum obligasi syariah Mudharabah.

\section{Uji Asumsi Klasik}

\section{a) Multikolinieritas}

Berdasarkan tabel diperoleh nilai VIF untuk kedua variabel dibawah 10 sehingga tidak terjadi multikolinieritas.

b) Heterokedastisitas

Berdasarkan tabel diperoleh keterangan bahwa tidak terdapat korelasi antara variabel bebas dengan residual sehingga tidak melanggar asumsi heterokedastisitas.

c) Autokorelasi

Berdasarkan hasil analisis diperoleh nilai D.W sebesar 1.948 sedangkan dl sebesar 1.36 dan du sebesar 1.65 . karena nilai DW berada diantara $\mathrm{du}=1.65 \mathrm{dan}(4-1.60=2.40)$ maka tidak terdapat autokorelasi. 


\section{PEMBAHASAN}

a Pengaruh Inflasi dan Tingkat Suku Bunga SBI Terhadap Return Obligasi Syariah Mudharabak

Berdasarkan nilai $F_{\text {hirung }}$ yang menunjukkan nilai sebesar 24.284 (signifikansi $F=0,000)$. Jadi Sig $F<5 \%(0,0.000<0,05)$ berarti secara bersama-sama variabel tingkat suku bunga SBI $\left(X_{1}\right)$ dan inflasi $\left(X_{2}\right)$ berpengaruh signifikan terhadap variabel retum obligasi syariah Mudharabah (Y) Dari nilai R Square menunjukkan nilai sebesar 0,555 atau 55,5\%. Artinya bahwa variabel retum obligasi syariah Mudharabah (Y) dipengaruhi sebesar $55,5 \%$ oleh tingkat suku bunga SBI (X1) dan inflasi (X2) sedangkan sisanya $44.5 \%$ dipengaruhi oleh variabel lain di luar 2 variabel bebas yang diteliti. Dalam obligasi syariah mudharabah, Emiten adalah Mudharib, sedangkan pemegang obligasi syariah mudharabah adalah Shahibul Maal. Dalam obligasi syariah mudharabah, besarnya keuntungan yang akan diperoleh tidak dapat diketahui di depan. Pada umumnya sulit didapat kepastian akan hasil investasi maupun pengembalian modal awal. Karena itu diperlukan inovasi untuk mengidentifikasi usaha spesifik yang akan dibiayai, menyalahi prinsip syariah atau tidak, bagaimana unsur biaya tetapnya, biaya variabel, dan unsur pendapatan yang berkaitan. Sementara itu mengingat sebenarnya Investor sebagai pemilik harta yang berhak sewaktu-waktu menarik kembali investasinya, maka dalam hal ini Investor harus membuat aqad jaiz berjanji untuk tidak menarik kembali investasinya kecuali mengikuti ketentuan dari perjanjian penerbitan obligasi syariah (Iwan P. Pontjowinoto: 2003). Sehingga mudharabah yang sering disebut sebagai trust financing ini hanya diberikan kepada pengusaha yang sudah teruji memegang amanah dengan baik. Apabila terjadi satu dan lain hal yang merugikan kedua belah pihak, hal itu tidak disebabkan oleh kesalahan pengelolaan si pengusaha, sehingga risiko dapat ditanggung bersama secara adil (Gunawan Yasni, Muhammad. Pembiayaan Syariah - Alcemarif Pengembangan Pembiayaan Modal Ventura Indonesia). Berdasarkan data tersebut di atas tergambarkan bahwa return Obligasi Syariah Mudharabah yang dibagikan oleh masing masing emiten jumlahnya tiap tahun bervariasi atau tidak tetap. Hal ini sesuai dengan 
ketentuan yang tertuang dalam obligasi syariah Mudharabah bahwa bagii hasil dihitung berdasarkan komponen pendapatan (revenue sharing) atau keuntungan (profit sharing).Kemampuan perusahaan dalam menghasilkan pendapatan atau keuntungan dipengaruhi oleh banyak faktor. Faktor itu terbagi dalam dua faktor yaitu, faktor dari dalam dan dari luar perusahaan. Faktor dari dalam perusahaan berkaitan dengan kemampuan secara internal (dari dalam) perusahaan untuk menghasilkan laba. Faktor ini dibatasi oleh kemampuan sumber dana dan sumber daya yang dimilki oleh perusahaan. Sedangkan faktor dari luar melingkupi variabel makro yang dapai mempengaruhi kinerja perusahaan. Variabel makro tersebut adalah inflasi, tingkat suku bunga SBI dll. Tingkat inflasi yang tinngi tidak akan menggalakkan perkembangan ekonomi. Biaya yang terus menerus meningkat akan menyebabkan kegiatan produktif tidak menguntungkan. Kenaikan harga secara terus menerus menimbulkan efek yang buruk pula pada perdagangan. Kenaikan harga tersebut menyebabkan produk tersebut tidak terjangkau oleh masyarakat dan akan mengalami kesulitan dalam bersaing di dunia internasional.

\section{b. Pengaruh Inflasi dan Tingkat Suku Bunga SBI Terhadap Return Obligasi Syariah Ijarah}

Dari nilai $F_{\text {hitung }}$ menunjukkan nilai sebesar 0.772 (signifikansi $F=$ $0,467)$. Jadi Sig F > 5\% $(0,467>0,05)$ berarti secara bersama-sama variabel tingkat suku bunga SBI $\left(\mathrm{X}_{1}\right)$ dan inflasi $\left(\mathrm{X}_{2}\right)$ tidak berpengaruh signifikan terhadap variabel return obligasi Ijarah (Y). Dengan demikian hipotesis yang menduga bahwa ada pengaruh yang signifikan dari variabel tingkat suku bunga SBI dan inflasi secara bersama-sama terhadap variabel retum obligasi syariah Ijarah tidak terbukti kebenarannya. Dari nilai $R$ Square menunjukkan nilai sebesar 0,029 atau $2,9 \%$. Artinya bahwa variabel retum obligasi syariah ljarah (Y) dipengaruhi sebesar $2,9 \%$ oleh tingkat suku bunga SBI (X1) dan inflasi (X2) sedangkan sisanya 97,1\% dipengaruhi oleh variabel lain di luar 2 variabel bebas yang diteliti. Dari hasil di atas menunjukkan bahwa secara simultan baik variabel tingkat suku bunga SBI maupun inflasi 
tidak berpengaruh signifikan terhadap retum obligasi syariah ljarah. Dalam obligasi syariah ijarah, keuntungannya sudah dapat diketahui secara pasti sejak awal, karena sifatnya sebagai sewa atas guna barang (fee / sewa). Maka hasil investasi bersifat mendekati pasti karena merupakan imbalan sewa/ upah atas pemakaian manfaat dari obyek pembiayaan. Skim ijarah (sewa) dinilai cukup prospektif bagi para Emiten yang bemiat menerbitkan obligasi syariah. Skim ini dalam beberapa hal lebih menguntungkan dari pada skim mudharabah (bagi hasil) (Republika Online, 2006). Obligasi syariah ijarah merupakan obligasi syariah yang dananya khusus digunakan untuk menyewa areal usaha. Imbalan hasil yang akan diberikan kepada para pemegang obligasi syariah ijarah tersebut didapatkan dari hasil sewa dengan tingkat fee ijarah tetap. Fee ijarah ini diperoleh dari penyewaan tempat dan telah ditentukan sebelumnya, bukan tergantung dari bagi hasil sebagaimana obligasi syariah mudharabah (Joe, 2006).

\section{Simpulan}

Berdasarkan hasil penelitian, maka dapat disimpulkan bahwa:

a. Secara simultan terdapat pengaruh yang signifikan inflasi dan tingkat suku bunga SBI terhadap retum obligasi syariah Mudharabah sehingga Ha diterima.

b. Secara simultan tidak terdapat pengaruh yang signifikan inflasi dan tingkat suku bunga SBI terhadap retum obligasi syariah ljarah sehingga Ha ditolak.

\section{Saran}

Berdasarkan pada penelitian yang telah dilakukan, maka saran yang diberikan adalah sebagai berikut:

a. Untuk peneliti selanjutnya diharapkan ada penambahan variable serta memperpanjang periode penelitian. Hal ini diharapkan agar penelitian berikutnya akan lebih menghasilkan hasil yang memuaskan 
b. Bagi investor yang berinvestasi pada ç̉ikgasi syariah khususnya obligasi syariah Mudharabah hendaknya memperhatikan kinerja keuangan yang dihasilkan oleh emiten. Karena kinerja keuangan yang dicapai oleh emiten memberikan pengaruh terhadap return obligasi syariah Mudharabah

c. Bagi calon investor sebelum berinvestasi pada obligasi syariah hendaknya melihat kredibilitas dan kemampuan emiten dalam mencapai kinerja keuangannya

d. Meningkatkan kinerja obligasi syariah agar tidak kalah dengan obligasi konvensional

e. Melakukan sosialisasi dalam rangka memberikan pemahaman kepada masyarakat luas tentang keberadaan obligasi syariah dengan melibatkan banyak pihak, seperti : pengamat, akademisi, ulama di bidang ekonomi syariah

\section{Daftar Pustaka}

Achsien, Iggi H, 2003. Investasi Syariah di Pasar Modal, Penerbit PT.Gramedia Pustaka Utama, Jakarta.

BAPEPAM, 2003. Panduan Investasi Di Pasar Modal Indonesia, Penerbit Badan Pengawas Pasar Modal (BAPEPAM) Bekerjasama Dengan Japan International Cooperation Agency.

Brigham, Eugene F, 2001. Manajemen Keuangan (Edisi Kedelapan), Penerbit PI Erlangga, Jakarta.

Buku Materi Islamic Banking Training Goes To Campus 2004. Universitas Brawijava Malang.Griffin, dkk, 1996. Bisnis, Prenhallindo, Jakarta.

Hidaya, Kanny, 2003. dalam Buku Materi Workshop Pasar Modal Syariah Obligasi, Makalah tidak diterbitkan.

Himpunan Fatwa Dewan Syariah National (DSN) Edisi Kedua, 2003. Penerbit PI' Internasa, Jakarta. 
Husnan, Suad dkk., 1993. Dasar-dasar Teori Porlofolio dan Analisis Sekutas, Penerbit UPP AMP YKPN, Yogyakarta.

Nopirin.2000. Ekonomi Moneter . Edisi Pertama. Yogyakarta:BPFE

Panduan Investasi Di Pasar Modal Indonesia. Badan Pengawas Pasar Modal Bekerjasama Dengan Japan International Cooperation Agency. 2003.

Pontjowinoto, Iwan, 2003. dalam Buku Materi Workshop Pasar Modal Syariah Ohligasi.

Warkum, 2004. Asas-asas Perbankan Islam dan I.embaga-lembaga Terkait (BAMUI, TAKAFUL, dan Pasar Modal Syariah di Indonesia), Penerbit PT. Raja Grafmdo Persada, Jakarta.

Syafri Harahap, Sofyan, 1993. Teori Akuntansi (Edisi Revisi), Penerbit PT. RajaGrafmdo Persada, Jakarta.

Siamat,D.2001. Manajemen Lembaga Keuangan . Edisin Ketiga Jakarta: Lembaga Penerbit FEUI

\section{Sumber Selain Buku;}

Achsien, Iggi H, Makalah. Mengintip Peluang Obligasi Syariah.

Hulwati, 2005. Makalah Legitmasi Obligasi Sebagai Instrumen Keuangan Islam. Info Bank. 1998, April, Fokus Utama,pp7

Majalah Modal, 2004, Edisi 23, Penerbit PT. Modal Multimedia, Jakarta. , 2005, Edisi 30, Penerbit PT. Modal Multimedia, Jakarta.

Tim Studi Tentang Investasi Syariah di Pasar Modal Indonesia, 2004.

Undang-undang Nomor 8 Tahun 1995 Tentang Pasar Modal

Yasni, M Gunawan, 2002. Mengenal Instrumen Pasar Modal Syariah, Republika.

Yasni, M Gunawan. Pembiayaan Syariah - Alternatif Pengembangan Pembiayaan Modal Ventura Indonesia. 
Yasni, M Gunawan dalam Prospektif, Obligasi Syariah Menawarken Trust, 10 September 2002.

02 Februari 2006, http: //www. Tempointeraktif com/hg/ekbis/2005/10/06/ brk,20051006-67616,id.html.

02 Februari 2006,tid,Republika) (syariahmandiri.co.id) http:72.14

05 Mei 2006, http://vwww.kompas.eom/kompas-cetak/0403/1 7/finansial/9 $18272 . \mathrm{htm}$.

24 Mei 2006, http://www.tempointeraktif.com/hg/ekbis/2005/08/08/ brk,20050808-64973,id.html.

Achsien, Iggi H. Mengenal Obligasi Syariah. 05 Mei 2006, http:/Nww. kompas.com/kom pas

Ekonomi Syariah Di Indonesia, 26 Mei2006, http:/www. tazkiaonline.com/arti.

Antonio, M Syafli. Riba dalam Perspektif Agama dan Sejarah (Terakhir), 1 8 Juli 2006, http://coolstuff.blubox.us/wp/?p: =l 11.

DSN MUI, Fatwa Dewan Syariah Nasional Majelis Ulama Indonesia Nomor: 41 DSN-MUI/II/2004 Tentang Obligasi Syariah Ijarah, 05 Mei2006.

Investasi Pasar Modal/Keuangan Dilihat dan Perspeklif Islam, 26 Mei 2006, www.tazkiaonline.com.

Joe, Emiten Mulai Minati Obligasi Syariah Ijarah, 06 Juni 2006, hetp://uruw.kompas.eom/kompas-cetak/0403/J 7/fmensial/918272.htm.

Ngapon, SemarakPasar Modal Syariah, 05 Mei 2006, http://www.bapepam.go.id/ayanan/warta/2005_april/semarak_syariah.pdf Overview, 21 JuJi 2006, http://www.bes. co. id/about/overview.asp.

Repubjika Online, Skim Ijarah Untuk Obligasi Prospektif, 06 Juni 2006, http://www. taziaonline. com/artikel. php $=391$. 